\title{
Glucarpidase to combat toxic levels of methotrexate in patients
}

This article was published in the following Dove Press journal:

Therapeutics and Clinical Risk Management

21 November 2012

Number of times this article has been viewed

\section{Jacalyn M Green}

Department of Biochemistry, Midwestern University, IL, USA

Correspondence: Jacalyn M Green Department of Biochemistry, Midwestern University, 555 3Ist Street,

Downers Grove, IL 605 I5, USA

$\mathrm{Tel}+\mathrm{I}(630) 5156155$

Fax + I (630) 5I5 6319

Email jgreen@midwestern.edu
Abstract: In January 2012, glucarpidase $\left(\right.$ Voraxaze $^{\circledR}$ ) received approval from the US Food and Drug Administration for intravenous treatment of toxic plasma methotrexate concentrations due to impaired renal clearance. Methotrexate, an antifolate agent, has been used for over 60 years in the treatment of various cancers. High-dose methotrexate has been particularly useful in the treatment of leukemias and lymphomas. However, even with aggressive hydration and urine alkalinization, such regimens can lead to acute renal dysfunction, as indicated by decreases in urine production and concomitant increases in blood urea nitrogen and serum creatinine levels. Because methotrexate is largely excreted by the kidneys, this can greatly potentiate tissue damage. Toxic levels of blood methotrexate can be rapidly and effectively decreased by intravenous administration of glucarpidase. Glucarpidase is a recombinant form of carboxypeptidase G2, a bacterial enzyme that rapidly cleaves methotrexate to form the amino acid glutamate and 2,4-diamino- $\mathrm{N}^{10}$-methylpteroic acid. Catabolites of methotrexate are much less toxic than the parent compound, and are primarily excreted by hepatic mechanisms. Glucarpidase has been available on a compassionate basis since the 1990s, and a variety of case reports and larger clinical trials have demonstrated the safety and efficacy of this drug in patients ranging in age from infants to the elderly and in a variety of races and ethnic groups. Glucarpidase should not be administered within 2 hours of leucovorin, because this agent is a reduced folate which competes with methotrexate for the enzyme and glucarpidase inactivates leucovorin. Side effects of glucarpidase are rare and relatively mild, and include paraesthesia, flushing, nausea, vomiting, pruritus, and headache. Glucarpidase has seen limited use in intrathecal treatment of methotrexate toxicity for which it is also effective. Future applications of this enzyme in chemotherapy continue to be an active area of research.

Keywords: glucarpidase, Voraxaze ${ }^{\circledR}$, carboxypeptidase G2, methotrexate, antifolate, chemotherapy

\section{Brief history of folate, methotrexate, and chemotherapy}

An understanding of glucarpidase depends on some knowledge of folic acid and methotrexate. In the earlier half of the 20th century, scientists were working out the dietary requirements for human health. During this time, it was recognized that vitamins were small molecules required in the diet, and that deficiencies resulted in specific syndromes. ${ }^{1,2}$ Folic acid, or vitamin B9, is a water-soluble vitamin which functions within cells in reduced forms, primarily as tetrahydrofolates subject to polyglutamylation by the enzyme folylpolyglutamate synthetase. Intracellular tetrahydrofolates act as carriers of a wide variety of one-carbon units, and can carry formyl, methenyl, methyl, 
and methylene groups. Each functions in specific pathways, including biosynthesis of purines, thymidylate, and amino acid metabolism. Adequate folate nutrition is therefore necessary for normal cell growth.

The fundamental role of folates in cell division, especially DNA synthesis, is why folic acid analogs (antifolates) such as methotrexate (amethopterin) and aminopterin, were explored as chemotherapeutic agents. ${ }^{3}$ In 1948, aminopterin was first successfully used to treat acute lymphocytic leukemia in children. ${ }^{4}$ Though remissions proved to be temporary, this study provided hope for this line of chemotherapy research. Aminopterin varies from folate by an amino group, while methotrexate also possesses an N-methyl group (Figure 1). This likely explains why subsequent studies showed methotrexate to have the more favorable therapeutic index. Methotrexate is taken up into cells via the same systems as reduced folates. ${ }^{5}$ During cellular metabolism, it is acted upon by folylpolyglutamate

\section{Folic acid}

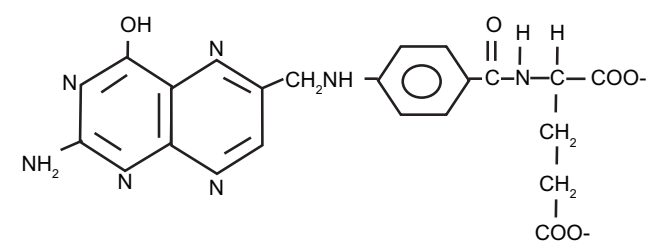

\section{Aminopterin}

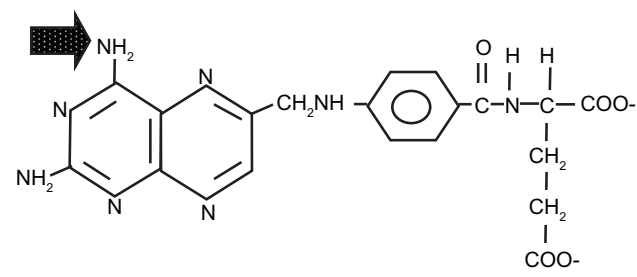

\section{Methotrexate}

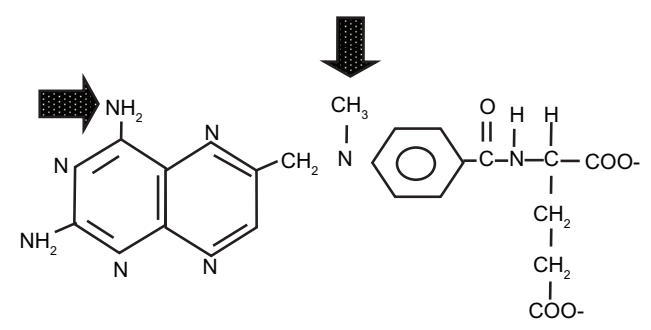

Figure I Structures of folic acid, aminopterin and methotrexate. Note: Differences among structures are highlighted with arrows. synthetase, which adds a polyglutamate tail. ${ }^{6}$ This tail both increases cellular retention and alters bioactivity. ${ }^{3}$ The classical target of methotrexate is dihydrofolate reductase, but methotrexate and its cellular metabolites accumulate within the cell and interfere with other reactions, including thymidylate synthase, further contributing to its action. ${ }^{6,7}$ Methotrexate is currently used to treat a variety of cancers, including bladder cancer, breast cancer, head and neck cancers, choriocarcinoma, acute lymphocytic leukemia, non-Hodgkin's lymphoma, lung cancer, osteosarcoma, meningeal leukemia and carcinomatous meningitis, gestational trophoblastic carcinomas, and colorectal cancer. ${ }^{8,9}$ Methotrexate is administered via the oral, intravenous, intra-arterial, and intrathecal routes. Side effects include myelosuppression (especially neutropenia), alopecia, nausea, vomiting, mucositis, renal damage, and occasionally portal fibrosis and cirrhosis. While common (and relatively minor) side effects of intrathecal methotrexate include headache, fever, vomiting, meningismus, erythematous rash, and pleocytosis of the cerebral spinal fluid, more severe toxicities can include paralysis, cranial nerve palsies, seizures, coma, demyelinating encephalopathy, and death. ${ }^{8,9}$

Because of the variety of pathologies for which methotrexate is prescribed, there is no standard dosing regimen. ${ }^{9}$ Methotrexate is used as a single low-dose oral medication for treatment of psoriasis and rheumatoid arthritis, though the mechanism of action is not understood and may not be related to inhibition of dihydrofolate reductase. ${ }^{10}$ Methotrexate is used in higher doses for acute lymphocytic leukemia and for central nervous system lymphomas. ${ }^{9}$ For other cancers, it is often used in combination with other medications. Intrathecal use of methotrexate may be as a single agent or in combination.

Renal toxicity is primarily associated with high-dose therapy, probably because the primary route of excretion for methotrexate and its metabolites is the kidneys. High-dose methotrexate therapy typically involves doses of $1-12 \mathrm{~g} / \mathrm{m}^{2}$, with the duration of infusion varying from 0.3 to 24 hours. ${ }^{11}$ Side effects vary depending on both the dose and schedule. Renal damage is thought to occur either by precipitation of methotrexate and its breakdown products in the renal tubules, or from a direct toxic effect of methotrexate. ${ }^{12,13}$ The solubility of methotrexate increases with $\mathrm{pH}$, so urine alkalinization and intravenous hydration are necessary treatments accompanying high-dose methotrexate. ${ }^{9}$ Patients should be screened for adequate hepatic, renal, and bone marrow function; urinary $\mathrm{pH}$ should be greater than 7.0, and urinary output should be greater than $100 \mathrm{~mL}$ per hour prior to administration of methotrexate. These are typically achieved 
and maintained with supplemental sodium bicarbonate and 2.5-3.5 L/m²/day of intravenous fluids. ${ }^{11}$

Some medications may increase the possibility of adverse drug reactions when coadministered with methotrexate, and may precipitate a need for glucarpidase treatment. ${ }^{8,14}$ The most common pharmacokinetic interaction observed clinically involves coadministration with one of the benzimidazole proton pump inhibitors; these compounds are associated with delayed elimination of methotrexate, and therefore an increased incidence of toxic levels of the antifolate. ${ }^{15}$

\section{History of carboxypeptidase 2 and related enzymes: purification, characterization, and cloning}

A variety of bacterial enzymes have been identified which can remove the carboxyl glutamate from folate and its analogs (Table 1). It was observed as early as 1955 that certain bacteria had the capacity to inactivate folate analogs such as methotrexate, presumably via enzymatic cleavage. ${ }^{16}$ Enzymes with the ability to cleave folate and its derivatives have largely been isolated from soil organisms. In 1967, Levy and Goldman published several studies in which they purified and characterized an enzyme from a Pseudomonas strain which could liberate glutamate from methotrexate $\left(\mathrm{K}_{\mathrm{m}} 200 \mu \mathrm{M}\right)$, aminopterin, and folate. ${ }^{17}$ At that time, the authors viewed the potential significance of the enzyme as a clinically useful assay for methotrexate levels in clinical samples. ${ }^{17,18}$ The following year, Pratt et al partially purified and characterized a similar enzyme from a Flavobacterium strain, which they termed folate amidase. ${ }^{19}$ Their study was motivated by the need to isolate large amounts of pteroic acid, which at the time was a limiting reagent for development of new folate antagonist chemotherapies. In 1971, carboxypeptidase G1 was isolated from Pseudomonas stutzeri, ${ }^{20}$ and compared with the enzymes of earlier studies, this enzyme was more purified and showed more favorable kinetic properties. Naturally reduced folates (including 5-methyl-tetrahydrofolate and 5-formyl-tetrahydrofolate, also known as leucovorin and citrovorum factor, respectively) were also excellent substrates, but with $\mathrm{K}_{\mathrm{m}}$ values in the $10-20 \mu \mathrm{M}$ range. These authors recognized the potential value of the enzyme, not only in preparing pteroic acid, but also as a potential antineoplastic agent, due to its ability to cleave both reduced and oxidized folates. In 1978, Albrecht et al partially characterized a carboxypeptidase from a Flavobacterium species. ${ }^{21}$

In 1983, the gene for carboxypeptidase G2 was cloned from Pseudomonas, first in Escherichia coli and subsequently in Pseudomonas putida; ${ }^{22}$ expression in the latter was 30 -fold higher than in E. coli. This protein possessed properties which were different from the earlier characterized carboxypeptidases, hence the distinct name. Carboxypeptidase G2 requires divalent zinc cations and is composed of two $42 \mathrm{kDa}$ subunits. The complete nucleotide sequence of the gene was subsequently determined. ${ }^{23}$ Optimized expression enabled enhanced purification yielding homogeneous protein. ${ }^{24}$ These studies demonstrated that among this family of enzymes, carboxypeptidase G2 displayed the best ability to differentiate between methotrexate and 5-methyl tetrahydrofolate $\left(\mathrm{CH}_{3} \mathrm{THF}\right)$, the circulating form of folate, and thereby paved the way for clinical use of recombinant

Table I Enzymes that cleave glutamate from methotrexate and folate. A low value for $\mathrm{K}_{\mathrm{m}}$ corresponds to an increased affinity for the substrate. The increasing ratio of $\left(\mathrm{K}_{\mathrm{m}} \mathrm{CH}_{3} \mathrm{THF} / \mathrm{K}_{\mathrm{m}}\right.$ methotrexate) correlates with the increasing affinity an enzyme shows for methotrexate over $\mathrm{CH}_{3}$ THF

\begin{tabular}{|c|c|c|c|c|}
\hline \multirow[t]{2}{*}{ Publication year } & \multirow[t]{2}{*}{ Enzyme name } & \multirow[t]{2}{*}{ Bacterial strain } & \multirow[t]{2}{*}{ Substrate $\left(K_{m}\right)$} & \multirow{2}{*}{$\begin{array}{l}\text { Ratio } \\
\frac{\mathrm{K}_{\mathrm{m}} \mathrm{CH}_{3} \mathrm{THF}}{\mathrm{K}_{\mathrm{m}} \text { methotrexate }}\end{array}$} \\
\hline & & & & \\
\hline $1967^{17}$ & Carboxypeptidase & Pseudomonas & $\begin{array}{l}\text { Methotrexate } 240 \mu \mathrm{M} \\
\text { Folate }<\mathrm{I} \mu \mathrm{M}\end{array}$ & - \\
\hline $1968^{19}$ & Folate amidase & Flavobacterium & Folate $91 \mu \mathrm{M}$ & - \\
\hline$|97|^{20}$ & Carboxypeptidase GI & $\begin{array}{l}\text { Pseudomonas } \\
\text { stutzeri }\end{array}$ & $\begin{array}{l}\text { Methotrexate } 3.9 \mu \mathrm{M} \\
\text { Folate I.I } \mu \mathrm{M} \\
\mathrm{CH}_{3} \text { THF } 12.9 \mu \mathrm{M}\end{array}$ & 3.3 \\
\hline $1978^{21}$ & Carboxypeptidase & Flavobacterium & $\begin{array}{l}\text { Methotrexate } 5 \mu \mathrm{M} \\
\text { Folate } 8.0 \mu \mathrm{M} \\
\mathrm{CH}_{3} \mathrm{THF} 5.7 \mu \mathrm{M}\end{array}$ & 1.14 \\
\hline $1983^{222,24}$ & Carboxypeptidase G2 & $\begin{array}{l}\text { Pseudomonas spp. } \\
\text { RS-16 }\end{array}$ & $\begin{array}{l}\text { Methotrexate } 8.0 \mu \mathrm{M} \\
\text { Folate } 4.0 \mu \mathrm{M} \\
\mathrm{CH}_{3} \text { THF } 34 \mu \mathrm{M}\end{array}$ & 4.25 \\
\hline
\end{tabular}

Abbreviation: $\mathrm{CH}_{3} \mathrm{THF}, 5$-methyl tetrahydrofolate. 
carboxypeptidase G2. Since carboxypeptidase G2 has found clinical application, the crystal structure of the enzyme has been analyzed as well, enabling the potential for designing enzymes with variable functionality. ${ }^{25}$

The physiological role of carboxypeptidase enzymes within the bacterial cell remains unknown. They may function in a folate catabolic or a salvage pathway similar to that proposed for $p$-aminobenzoyl-glutamate hydrolase, a manganese-dependent enzyme isolated from $E$. coli which hydrolyzes $p$-aminobenzoyl-glutamate, the folate catabolite, to form $p$-aminobenzoic acid and glutamate. ${ }^{26-28}$ However, folate is a very poor substrate for this enzyme.

\section{Mechanism of action of glucarpidase}

As an enzyme, glucarpidase rapidly converts methotrexate to the amino acid glutamate and 2,4-diamino- $\mathrm{N}^{10}$-methylpteroic acid (DAMPA, see Figure 2). ${ }^{24}$ Using Rhesus monkeys, Widemann et al studied the pharmacokinetics and metabolism of DAMPA. ${ }^{29}$ DAMPA was infused over 15 minutes into the monkeys; after reaching a serum concentration of about $50 \mu \mathrm{M}$, DAMPA was eliminated rapidly, falling to less than $1 \mu \mathrm{M}$ within $1-2$ hours. About $50 \%$ of the DAMPA was excreted in urine and about $50 \%$ was metabolized by the liver into hydroxyl-DAMPA, DAMPA-glucuronide, and hydroxy-DAMPA-glucuronide. These latter compounds were identified in both the blood and urine of the monkeys, and also in similar samples from patients treated for methotrexate toxicity with carboxypeptidase G2. Using a human leukemic cell line, they found that DAMPA was not toxic in itself, nor
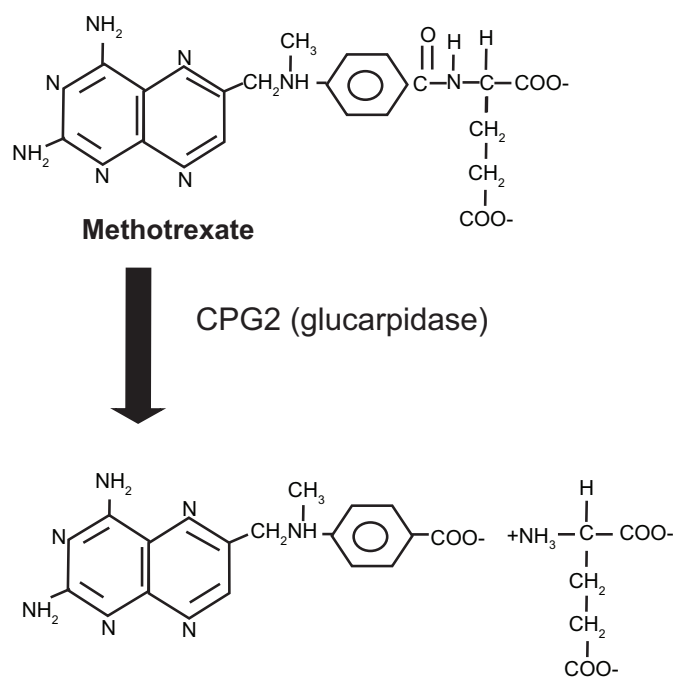

DAMPA

Glutamate

Figure 2 The reaction catalyzed by glucarpidase (CPG2). Note: Methotrexate is cleaved to form DAMPA and glutamate.

did it alter the cytotoxicity of methotrexate. They concluded that conversion of methotrexate to DAMPA relieves stress on the kidneys for elimination of methotrexate and generates a relatively nontoxic compound.

Successful cleavage of methotrexate by glucarpidase results in elevations of glutamate and DAMPA in the bloodstream. Because methotrexate levels are frequently monitored during patient treatment, one should note that DAMPA can interfere with such monitoring. Methotrexate can be measured using a variety of tests, including dihydrofolate reductase assays, an antibody-based immunoassay, and a high-pressure liquid chromatography method. ${ }^{30}$ However, the antibody-based methods cross-react with the breakdown products of methotrexate, and are not a reliable measure of methotrexate levels in samples from patients after treatment with glucarpidase.

\section{Animal studies of carboxypeptidase G2 for methotrexate toxicity}

There are only two animal studies in the literature concerning use of carboxypeptidase G2 for treatment of methotrexate overdose. The first study, in 1991, involved use of adult Rhesus monkeys to investigate intrathecal carboxypeptidase G2 for treatment of intrathecal overdose of methotrexate. ${ }^{31}$ Using three groups (with three monkeys per group), they first determined the pharmacokinetics in cerebrospinal fluid. One group received methotrexate alone $(5 \mathrm{mg}$, equivalent to $50 \mathrm{mg}$ for humans), another group received methotrexate followed by carboxypeptidase G2 (30 U) five minutes later, and another group received carboxypeptidase G2 alone. In the first group of monkeys, methotrexate reached a concentration of about $3000 \mu \mathrm{M}$ in the cerebrospinal fluid, with an area under the curve of about $4300 \mu \mathrm{M} \times$ hour. In the group treated with methotrexate and carboxypeptidase G2, cerebrospinal fluid levels of methotrexate decreased by greater than 400-fold within 5 minutes of carboxypeptidase G2 administration; the area under the curve decreased by 80 -fold to about $51 \mu \mathrm{M} \times$ hour. Elevations in mononuclear cells were observed in the cerebrospinal fluid of animals receiving carboxypeptidase $\mathrm{G} 2$ alone, but no symptoms were apparent. In the second phase of experiments, monkeys were subjected to a toxic intrathecal methotrexate dose and were then rescued using carboxypeptidase G2. Two groups of three monkeys each were either treated with $25 \mathrm{mg}$ or $50 \mathrm{mg}$ of intrathecal methotrexate, followed immediately by $150 \mathrm{U}$ or $300 \mathrm{U}$, respectively, of intrathecal carboxypeptidase G2. These methotrexate doses were equivalent to $250 \mathrm{mg}$ or $500 \mathrm{mg}$ in humans. While one monkey (receiving the $25 \mathrm{mg}$ 
dose) experienced a seizure, all six monkeys, regardless of dose, were successfully rescued by carboxypeptidase G2, which reduced the methotrexate levels in all animals by about 1000-fold. However, all animals also demonstrated an asymptomatic elevation of mononucleocytes in cerebrospinal fluid. The data from this study show that carboxypeptidase G2 is promising as a rescue agent for intrathecal methotrexate toxicity.

Follow-up studies in monkeys were performed to investigate the pharmacokinetics of carboxypeptidase G2 as an alternative to leucovorin for "rescue" treatment of toxic overdoses in serum, and as a secondary goal, they investigated the effects of anti-carboxypeptidase G2 antibodies on the effectiveness of carboxypeptidase G2. ${ }^{32}$ Leucovorin (5-formyltetrahydrofolate) is a form of reduced folate. Like methotrexate (and unlike carboxypeptidase G2) it is taken up and metabolized by cells. While leucovorin administration was commonly used as a rescue agent, it was unclear whether tumor cells were rescued as well as nontumor cells. To investigate the possible superiority of carboxypeptidase G2 as a rescue agent, two groups of monkeys (three in each group) were studied. One group was given a loading dose followed by a continuous 18 -hour intravenous infusion of methotrexate designed to maintain a steady-state plasma concentration of approximately $10 \mu \mathrm{M}$. At the end of the infusion, carboxypeptidase G2 $50 \mathrm{U} / \mathrm{kg}$ was administered. Three control animals were treated similarly with methotrexate, but with saline substituted for the carboxypeptidase G2. The results showed that the average concentration of methotrexate during infusion was maintained at $11 \mu \mathrm{M}$. Treatment with carboxypeptidase G2 diminished plasma methotrexate levels by over 100-fold within 15 minutes, and nontoxic levels of methotrexate were achieved within 30 minutes of administration of carboxypeptidase G2. The post-infusion area under the curve for the methotrexate-infused animals treated or untreated with carboxypeptidase G2 was $301 \mu \mathrm{M}$ and 20 $\mu \mathrm{M}$, respectively. With regard to the secondary goal, monkeys were treated with repeated doses of carboxypeptidase G2 over time to generate antibodies. It was hypothesized that because carboxypeptidase $\mathrm{G} 2$ is a protein, it would stimulate synthesis of antibodies, which might bind to and diminish the effectiveness of the enzyme. Using animals confirmed to have high titers of anticarboxypeptidase G2 antibodies, the researchers administered intravenous methotrexate followed by carboxypeptidase $\mathrm{G} 2$ rescue. This demonstrated that even in the presence of antibodies, carboxypeptidase G2 still significantly reduced plasma methotrexate concentrations, although the effect was less dramatic than that observed in antibody-negative animals. The authors concluded that carboxypeptidase G2 was a very promising treatment for methotrexate toxicity, with the potential to supplant leucovorin.

While the above two studies are the only ones involving animals and carboxypeptidase G2, there are earlier studies describing successful use of carboxypeptidase G1 to reduce plasma methotrexate levels, which provided the foundation for later work. In 1972, Chabner et al demonstrated that carboxypeptidase G1 successfully reduced plasma methotrexate levels in mice. ${ }^{33}$ As part of this study, they also performed an experiment in which mice injected with leukemia cells were subsequently treated with methotrexate, methotrexate with leucovorin rescue, or methotrexate with carboxypeptidase G1 rescue. The latter two groups showed very similar protection from methotrexate toxicity. Further studies with carboxypeptidase G1 were not performed owing to loss of the bacterial source.

\section{Clinical studies of glucarpidase for methotrexate overdose}

The need to have treatment available for methotrexate overdose results in part from the observation that individuals vary widely in their tolerance to methotrexate, ${ }^{34}$ with one study of 49 cancer patients observing that the dose causing toxic effects varied between 50 and $900 \mathrm{mg} / \mathrm{m}^{2}$, ie, by a factor of $18 .{ }^{35}$ The same study investigated the predictive power of various patient characteristics with regard to the potential for a patient to experience an adverse response to methotrexate. They studied a number of factors including history of previous chemotherapy or radiation treatment, weight loss, serum albumin levels, pretreatment blood folate levels, and age. Age was the only factor found to have a predictive value. The authors suggested that this might be due to diminished renal function, which is commonly found in the elderly patient population.

Chabner et al first suggested that enzymatic cleavage of methotrexate might be used clinically in patients suffering from antifolate toxicity back in $1972 .{ }^{33}$ Because glucarpidase is used to treat dangerously high levels of methotrexate that occur due to impaired metabolism or accidental overdose, there have been no clinical studies involving a control group. However, there are a number of case studies, as well as studies involving small numbers of patients, made possible by the availability of glucarpidase on a compassionate basis for patients experiencing nephrotoxicity 
following high-dose methotrexate. Carboxypeptidase G2 was used for the first time in 1995 in an 18-year-old woman with osteosarcoma who had been treated with high-dose methotrexate and developed signs of hepatic and renal damage; in this patient, leucovorin rescue was associated with hypercalcemia and ventricular arrhythmia. Administration of carboxypeptidase G2 successfully decreased the patient's methotrexate levels and she eventually recovered. ${ }^{36}$ Shortly after this case, and subsequent to their very promising animal studies, Widemann et al carried out a study in 20 patients with a variety of cancers, including osteosarcoma, lymphoid cancer, and gastric cancer. Following treatment with carboxypeptidase $\mathrm{G} 2$ and thymidine, all patients experienced a rapid 95\%-99\% reduction in plasma methotrexate levels, and their serum creatinine levels returned to normal after a median of about 3 weeks. ${ }^{37}$ In the ensuing decades, a number of reports have been published detailing successful carboxypeptidase G2 treatment in patients with acute renal failure stemming from use of high-dose methotrexate to treat cancer, primarily lymphoma ${ }^{38-40}$ and osteosarcoma. ${ }^{40-45}$ These studies have involved both male and female patients, ranging in age from 13 years ${ }^{42,46}$ to 79 years. ${ }^{39}$ While most of these patients have been from the US or Europe and of nonspecified race or ethnicity, patients known to be Korean, ${ }^{42}$ Hispanic, ${ }^{44}$ and Middle Eastern ${ }^{45}$ have been treated successfully.

In the last ten years, several larger studies have further corroborated the promise of carboxypeptidase G2 in the treatment of methotrexate overdose on a background of renal failure (Table 2). In 2005, Buchen et al reported a Phase II study in which carboxypeptidase G2 was administered to 82 patients experiencing acute symptoms related to methotrexate overdose and concomitant renal failure. ${ }^{47}$ This was a prospective, open, nonrandomized multicenter trial in patients with a median age of about 15 (range 0.9-71.8) years. Eligibility criteria included serum methotrexate levels $>10 \mu \mathrm{M}$ at 36 hours or $>5 \mu \mathrm{M}$ at 42 hours after starting an infusion of methotrexate and documented renal failure. Patients suffered from a range of cancers, including acute lymphocytic leukemia, non-Hodgkin's lymphoma, osteosarcoma, brain tumors, Hodgkin's lymphoma, and pleural mesothelioma. The target carboxypeptidase G2 dose was $50 \mathrm{U}$ per $\mathrm{kg}$ of body weight. At 15 minutes after administration of carboxypeptidase G2, the methotrexate serum level was reduced by approximately $87 \%$ and most patients survived. Despite treatment, four patients died of myelosuppression and septic complications. Because the previous study involved primarily children, Schwartz et al subsequently performed a similar study in Europe involving
43 adult and elderly cancer patients with acute lymphocytic leukemia, lymphoma, germ cell tumor, or osteosarcoma. ${ }^{48}$ Patients received glucarpidase, followed by leucovorin rescue and standard care. In the 24 patients with samples available, serum methotrexate levels decreased by $>97 \%$ in a median of 15 minutes after injection of carboxypeptidase G2. Ten of the 43 patients died of complications associated with high-dose methotrexate. Three patients were treated with glucarpidase twice during the same cycle of high-dose methotrexate; in two patients, the glucarpidase response was diminished, while serum methotrexate levels became undetectable in the third patient. The authors speculated that this might be due to inhibition of glucarpidase by DAMPA, or possibly as a result of an immune response to the enzyme.

Widemann et al performed a retrospective study of 100 cancer patients who received glucarpidase, leucovorin, and in some cases thymidine, for treatment of renal failure induced by high-dose methotrexate (Table 2). ${ }^{49}$ Patients ranged in age from 0.3 to 82 years and suffered from a range of cancers. The plasma methotrexate concentration decreased by $98 \%$ within 15 minutes of injection of glucarpidase. However, administration of thymidine did not provide any additional benefit. Of the 12 patients who died, six succumbed to irreversible methotrexate toxicity and organ damage. Multiple-regression analysis identified the presence of grade 4 toxicity before glucarpidase treatment, inadequate leucovorin dosing, and glucarpidase treatment more than 96 hours after methotrexate infusion as risk factors for grade 4 and 5 methotrexate toxicity. Interestingly, 28 patients received two glucarpidase doses 24 hours apart, and seven received three glucarpidase doses every 4 hours, and glucarpidase antibodies were not detected at 3, 7, or 14 days after treatment in any of these patients. The investigators concluded that early intervention with leucovorin and glucarpidase was highly effective in the treatment of renal failure induced by high-dose methotrexate, and that repeated use of glucarpidase was possible.

In 2011, researchers at St Jude Children's Research Hospital undertook a retrospective study of pediatric cancer patients treated with high-dose methotrexate between 1998 and 2010, some of whom had received glucarpidase for nephrotoxicity. The goal of this study was to determine the safety of resuming treatment with methotrexate following such treatment. ${ }^{50}$ Of 20 children who received glucarpidase, 13 were later treated again with methotrexate. Although one patient suffered neurotoxicity with further high-dose methotrexate, renal function returned to baseline in all patients, and all survived treatment. This study 
Table 2 Summary of recent studies using glucarpidase for methotrexate toxicity

\begin{tabular}{|c|c|c|c|}
\hline & Buchen et $\mathrm{al}^{47}$ & Schwartz et al ${ }^{48}$ & Wideman et al $^{49}$ \\
\hline Number of patients (F/M) & $\begin{array}{l}82 \text { (65 for whom data were } \\
\text { available) }(24 / 4 I)\end{array}$ & $43(\mathrm{II} / 32)$ & $100(37 / 63)$ \\
\hline Age, years, range (median) & $0.9-71.8(15.4)$ & I8-78 (54) & $0.3-82(17)$ \\
\hline $\begin{array}{l}\text { Pathologies represented } \\
\text { (number of patients) }\end{array}$ & $\begin{array}{l}\text { ALL (26) } \\
\text { Non-Hodgkin's lymphoma (2I) } \\
\text { Osteosarcoma (I2) } \\
\text { Other (6) }\end{array}$ & $\begin{array}{l}\text { ALL (I3) } \\
\text { Lymphoma (I2) } \\
\text { CNS lymphoma (16) } \\
\text { Other (2) }\end{array}$ & $\begin{array}{l}\text { Osteosarcoma (42) } \\
\text { Non-Hodgkin's lymphoma or } \\
\text { ALL (49) } \\
\text { Other (9) }\end{array}$ \\
\hline Methotrexate dose (range) & $1-12 \mathrm{~g} / \mathrm{m}^{2}$ & $\begin{array}{l}1.2-12.1 \mathrm{~g} / \mathrm{m}^{2} \text { in } 3-6 \text { hours } \\
(\mathrm{n}=20) \\
0.9-5 \mathrm{~g} / \mathrm{m}^{2} \text { in } 23-26 \text { hours } \\
(\mathrm{n}=23)\end{array}$ & $0.4-12 \mathrm{~g} / \mathrm{m}^{2}$ (median 7.7$)$ \\
\hline $\begin{array}{l}\text { Patient eligibility } \\
\text { (methotrexate levels } \\
\text { are monitored over time } \\
\text { following methotrexate } \\
\text { infusion) }\end{array}$ & $\begin{array}{l}\text { Serum methotrexate }>10 \mu \mathrm{M} \\
\text { at } 36 \text { hours or } \\
\text { Serum methotrexate }>5 \mu \mathrm{M} \\
\text { at } 42 \text { hours or } \\
\text { Serum methotrexate }>3 \mu \mathrm{M} \\
\text { at } 48 \text { hours; and decreased diuresis } \\
\text { or serum creatinine }>1.5 \times \text { ULN }\end{array}$ & $\begin{array}{l}\text { Serum methotrexate }>5 \mu M \\
\text { at } 42 \text { hours or later, or } \\
\text { serum methotrexate }>I \mu M \\
\text { at } 42 \text { hours or later with signs } \\
\text { of renal failure (oliguria and/or } \\
\text { serum creatinine }>1.5 \times \text { ULN) } \\
\text { or serum methotrexate }>0.4 \mu M \\
\text { at } 48 \text { hours or later and signs } \\
\text { of renal failure (see above) }\end{array}$ & $\begin{array}{l}\text { Serum methotrexate } \geq 10 \mu \mathrm{M} \\
\text { at } 42 \text { hours or later, or } \\
\text { serum creatinine was }>1.5 \mathrm{ULN} \\
\text { or creatinine clearance } \\
\text { was } \leq 60 \mathrm{~mL} / \mathrm{min} / \mathrm{m}^{2} \text { and serum } \\
\text { methotrexate was } \geq 2 \text { standard } \\
\text { deviations above the mean } \geq \\
12 \text { hours after methotrexate } \\
\text { administration }\end{array}$ \\
\hline $\begin{array}{l}\text { Serum methotrexate level } \\
\text { immediately before } \\
\text { glucarpidase dose, range } \\
\text { (median) }\end{array}$ & $0.52-901$ (II.93) $\mu \mathrm{M}$ & $1.0-1187(10.5) \mu \mathrm{M}$ & $0.37-849$ (I7) $\mu \mathrm{M}$ \\
\hline $\begin{array}{l}\text { Time of first glucarpidase } \\
\text { dose relative to start } \\
\text { of methotrexate infusion } \\
\text { range (median) }\end{array}$ & $25-178(52)$ hours & $27-176(56)$ hours & $\begin{array}{l}22-294(96) \text { hours for } 44 \text { patients } \\
\text { also receiving thymidine; } 22-192 \\
\text { (66) hours for } 56 \text { patients not } \\
\text { also receiving thymidine }\end{array}$ \\
\hline $\begin{array}{l}\text { First glucarpidase dose } \\
\text { range (median) }\end{array}$ & $33-60(50) \mathrm{U} / \mathrm{kg}$ & $10-58(50) \mathrm{U} / \mathrm{kg}$ & $50 \mathrm{U} / \mathrm{kg}$ \\
\hline $\begin{array}{l}\text { Glucarpidase doses (number } \\
\text { of patients) }\end{array}$ & $\begin{array}{l}\text { One dose (58) } \\
\text { Two doses (9) } \\
\text { Three doses (I) }\end{array}$ & $\begin{array}{l}\text { One dose (40) } \\
\text { Two doses (3) }\end{array}$ & $\begin{array}{l}\text { One dose }(65) \\
\text { Two doses }(28 ; 24 \text { hours apart) } \\
\text { Three ( } 7 \text {; every } 4 \text { hours })\end{array}$ \\
\hline $\begin{array}{l}\text { \% decrease in serum } \\
\text { methotrexate } \\
\text { (determined by HPLC) } \\
\text { Range (median) }\end{array}$ & $\begin{array}{l}73 \%-99 \%(97 \%) \text { ( } 15 \text { minutes after } \\
\text { glucarpidase treatment) }\end{array}$ & $\begin{array}{l}97 \% \text { reduction within } 7-50 \\
\text { (median I5) minutes; based on } \\
\text { samples from } 24 \text { patients }\end{array}$ & $\begin{array}{l}98.7 \% \text { (I5 minutes after } \\
\text { glucarpidase treatment) }\end{array}$ \\
\hline $\begin{array}{l}\text { Patient deaths owing to } \\
\text { methotrexate toxicity }\end{array}$ & $4 / 82(5 \%)$ & $10 / 43(23 \%)$ & $6 / 100(6 \%)$ \\
\hline $\begin{array}{l}\text { Glucarpidase side } \\
\text { effects observed (number } \\
\text { of patients, \%) }\end{array}$ & Flushing ( $2 \%)$, shaking (I\%) & Fever $(2 \%)$, pruritus $(2 \%)$ & $\begin{array}{l}\text { Flushing }(2 \%) \text {, feeling of } \\
\text { warmth ( } 2 \%) \text {, tingling fingers } \\
(1 \%) \text {, head pressure ( } 1 \%), \\
\text { numbness and burning }(2 \%) \text {, rash } \\
(1 \%) \text {, erythema and pruritus ( } 1 \%)\end{array}$ \\
\hline Glucarpidase antibodies & ND & $3 / 7$ patients $(43 \%)$ & $0 / 100$ \\
\hline
\end{tabular}

Abbreviations: CNS, central nervous system; ALL, acute lymphoblastic leukemia; HPLC, high-performance liquid chromatography; ULN, upper limit of normal; ND, not determined.

demonstrates that high-dose methotrexate treatment can be resumed after treatment with glucarpidase for methotrexate nephrotoxicity.

Widemann et al analyzed data from 492 cancer patients in the US and the European Union who were treated with glucarpidase for methotrexate toxicity between 1993 and 2009; while not yet published, this work was presented at the American Society of Clinical Oncology annual meeting in 2012. ${ }^{51}$ Most (94\%) of the patients had non-Hodgkin's lymphoma, osteogenic sarcoma, or acute lymphocytic leukemia, and ranged in age from 5 weeks to 85 years, with a median age of 18 years. While $76 \%$ of these patients had one dose of glucarpidase, $22 \%$ had two doses, and $2 \%$ had three doses. Of the 156 patients for whom reliable data 
were available, blood methotrexate levels decreased by a median of $99 \%$ relative to the preglucarpidase baseline at 15 minutes after administration of glucarpidase. Adverse reactions included paresthesia $(2 \%)$, flushing $(1.8 \%)$, and headache $(1 \%)$. The patients who died within 30 days of glucarpidase treatment ( $8 \%$ ) succumbed for reasons unrelated to glucarpidase.

\section{Pharmacokinetics of glucarpidase}

In 2008, Phillips et al performed an open-label, single-site pharmacokinetic study in which 12 adult volunteers without cancer received glucarpidase. ${ }^{52}$ Eight subjects had normal renal function and four had impaired renal function. Each subject received a single intravenous dose of glucarpidase $50 \mathrm{U} / \mathrm{kg}$. Subjects with normal renal function had a mean maximum serum glucarpidase concentration of $31 \mu \mathrm{g} / \mathrm{mL}$, with a mean half-life of 9.0 hours and a mean area under the serum concentration-time curve of $23.4 \mu \mathrm{g} \times \mathrm{h} / \mathrm{mL}$. The data for subjects with renal impairment were similar, indicating that renal impairment has a minimal effect on the pharmacokinetics of glucarpidase in the bloodstream.

\section{Drug interactions between glucarpidase and leucovorin}

Glucarpidase should not be administered simultaneously with leucovorin, because leucovorin serves as an alternative substrate and therefore can compete with methotrexate for the enzyme. Also, leucovorin is inactivated by glucarpidase. ${ }^{49,53}$ While glucarpidase is effective for reducing methotrexate levels in the bloodstream, it has no effect on intracellular methotrexate; because leucovorin enters cells, it combats intracellular methotrexate. Therefore, coadministration of leucovorin and carboxypeptidase G2 diminishes the effectiveness of both medications. Leucovorin rescue is often used in chemotherapy regimens in which the antifolate is administered first, and after some period of delay, leucovorin is then given. ${ }^{54-56}$ The goal is to kill tumor cells, which typically grow rapidly and therefore take up more folate (and therefore also antifolate), and then "rescue" the normal host cells. This approach was first successfully demonstrated as early as 1954 in a mouse model of leukemia, in which Goldin et al showed that aminopterin followed by delayed administration of citrovorum factor (leucovorin) was more effective than aminopterin used alone. ${ }^{57}$ Since that time, administration of methotrexate partnered with leucovorin rescue has become an established therapy for a variety of cancers. ${ }^{9}$ It is interesting that early studies in the area of treatment for methotrexate overdose also investigated the use of carboxypeptidase G2, not as a rescue agent but as a method whereby folate levels in the bloodstream might be reduced in order to enhance the biologic effectiveness of the antifolate. ${ }^{58}$

\section{Side effects of glucarpidase}

Adverse reactions to glucarpidase are rare, but include paresthesia, flushing, nausea and/or vomiting, hypotension, pruritus, fever, and headache. ${ }^{37,47,59}$

\section{Dosing}

Glucarpidase $\left(\right.$ Voraxaze $^{\circledR}$ ) is administered as a single intravenous injection of $50 \mathrm{U} / \mathrm{kg}$ body weight. ${ }^{60}$ It is supplied as a lyophilized powder, with $1000 \mathrm{U}$ per vial. Treatment with glucarpidase is warranted in patients with plasma methotrexate concentrations greater than $1 \mu \mathrm{M}$ and concomitant impaired renal function. Leucovorin should not be administered within 2 hours before or after a dose of glucarpidase.

\section{Intrathecal use}

Methotrexate is used intrathecally for the treatment of cancer, usually leukemia, or to prevent metastasis via the cerebrospinal fluid. However, intrathecal overdose of methotrexate can be fatal. Given the very promising data obtained in the animal studies in which monkeys administered lethal doses of methotrexate were rescued with carboxypeptidase G2, ${ }^{31}$ it is perhaps not surprising that accidental intrathecal methotrexate overdose has been successfully treated with carboxypeptidase G2. The first case involved a 6-year-old boy with acute lymphocytic leukemia who received $600 \mathrm{mg}$ of methotrexate rather than the intended $12 \mathrm{mg}$; despite acute neurotoxic symptoms he recovered fully after receiving $2000 \mathrm{U}$ of intrathecal carboxypeptidase G2, which decreased his cerebrospinal fluid methotrexate by 150 -fold. ${ }^{61}$ Similarly, other patients with accidental intrathecal methotrexate overdose have been treated successfully with carboxypeptidase G2, although in several instances the patients also underwent cerebrospinal fluid exchange. ${ }^{62}$ These data, although limited, suggest that carboxypeptidase G2 is a safe and effective treatment for accidental intrathecal methotrexate overdose.

\section{Impact of pharmacogenomics}

Recent advances in the burgeoning field of pharmacogenomics have resulted in greatly increased knowledge of the individual genetic alterations affecting drug metabolism, including methotrexate. Altered genes impacting methotrexate 
metabolism could encode for proteins involved in transport, metabolism, or function of folates and antifolates. Such differences could explain both lack of efficacy and increased toxicity. Several papers have described studies in which gene polymorphisms have been identified that impact methotrexate uptake and metabolism. ${ }^{63,64}$ While at this time one cannot order a battery of genetic tests to determine methotrexate dosing better, this sort of testing and personal dosing is on the horizon, and will possibly decrease the occurrence of toxic side effects (and the need for glucarpidase).

\section{Other potential clinical applications for carboxypeptidase $\mathbf{G} 2$}

A variety of alternative applications have been explored for bacterial carboxypeptidases. In 1972, carboxypeptidase G1 was used to deplete blood folate in a mouse leukemia model, which demonstrated that depletion of folate both successfully decreased blood folate and prolonged survival in mice. ${ }^{65}$ Later studies demonstrated that simultaneous administration of carboxypeptidase G1 and nonclassical folate antagonists (which the enzyme did not cleave) enhanced the antitumor effects of the drugs. ${ }^{66,67}$ In 1987, carboxypeptidase G2 was covalently linked to soluble dextran and injected into mice ${ }^{68}$ and this dextran-carboxypeptidase G2 conjugate had a prolonged lifetime in the circulation. The authors proposed using such systems to target therapeutic enzymes specifically to the liver. Similarly, carboxypeptidase G2 has been used in a two-step treatment mouse model of human choriocarcinoma. ${ }^{69-72}$ First, carboxypeptidase G2 was conjugated with a fragment of a monoclonal antibody attached to a subunit of human chorionic gonadotrophin. This was then used in conjunction with a prodrug consisting of a toxin attached to a substrate of carboxypeptidase G2. After the modified antibody-carboxypeptidase G2 conjugate was injected and allowed to localize to the tumor, the modified toxin-prodrug was injected, and the carboxypeptidase G2 released the active drug only at the tumor sites. Similarly, carboxypeptidase G2 has been used to activate phenol mustard prodrugs. ${ }^{73,74}$ More recently, carboxypeptidase G2 has been used in gene-directed enzyme prodrug therapy; this two-step approach involves first introducing the gene for carboxypeptidase G2 into the tumor via a virus or liposome, then allowing sufficient time for protein expression. Subsequently, the nontoxic prodrug is administered, and is activated specifically at the tumor site by carboxypeptidase G2. ${ }^{75,76}$ This strategy will be used in a Phase I clinical study involving patients with head and neck cancer. ${ }^{77}$ It is clear that glucarpidase or perhaps a similarly modified form of carboxypeptidase G2 may find new roles in the fight against cancer.

\section{Acknowledgments}

The expert assistance of Catherine Lencioni with internet research and reference management is gratefully acknowledged. This work was supported by funds from Midwestern University and by award number R15 GM085760 from the National Institute of General Medical Sciences.

\section{Disclosure}

The content of this paper is solely the responsibility of the author and does not necessarily represent the official views of the National Institutes of Health.

\section{References}

1. Hitchings GH, Burchall JJ. Inhibition of folate biosynthesis and function as a basis for chemotherapy. Adv Enzymol. 1965;27:417-468.

2. Carmel R. Folic acid. In: Shike M, Ross AC, editors. Modern Nutrition in Health and Disease. 10th ed. Philadelphia, PA: Lippincott Williams \& Wilkins; 2006.

3. Bertino JR. Karnofsky memorial lecture. Ode to methotrexate. J Clin Oncol. 1993;11:5-14.

4. Heinle RW, Welch AD. Experiments with pteroylglutamic acid and pteroylglutamic acid deficiency in human leukemia. J Clin Invest. 1948;27:539.

5. Matherly LH, Hou Z, Deng Y. Human reduced folate carrier: translation of basic biology to cancer etiology and therapy. Cancer Metastasis Rev. 2007;26:111-128.

6. Chabner BA, Allegra CJ, Curt GA, et al. Polyglutamation of methotrexate. Is methotrexate a prodrug? J Clin Invest. 1985;76:907-912.

7. Rosenfelt F. Methotrexate and the need for continued research. Yale $J$ Biol Med. 1975;48:97-103.

8. Skeel RT. Antineoplastic drugs and biologic response modifiers: classification, use, and toxicity of clinically useful agents. In: Skeel RT, editor. Handbook of Cancer Chemotherapy. 7th ed. Philadelphia, PA: Lippincott Williams \& Wilkins; 2003.

9. Perry MC. The Chemotherapy Source Book. 4th ed. Philadelphia, PA: Lippincott Williams \& Wilkins; 2008.

10. Kemper AR, Van Mater HA, Coeytaux RR, Williams JW Jr, Sanders GD. Systematic review of disease-modifying antirheumatic drugs for juvenile idiopathic arthritis. BMC Pediatr. 2012;12:29.

11. Chabner BA, Allegra CJ. Antifolates. In: Chabner BA, Longo DL, editors. Cancer Chemotherapy and Biotherapy: Principles and Practice. 5th ed. Philadelphia, PA: Lippincott, Williams \& Wilkins; 2010.

12. Treon SP, Chabner BA. Concepts in use of high-dose methotrexate therapy. Clin Chem. 1996;42:1322-1329.

13. Widemann BC, Adamson PC. Understanding and managing methotrexate nephrotoxicity. Oncologist. 2006;11:694-703.

14. Leveque D, Santucci R, Gourieux B, Herbrecht R. Pharmacokinetic drug-drug interactions with methotrexate in oncology. Expert Rev Clin Pharmacol. 2011;4:743-750.

15. Joerger M, Huitema AD, van den Bongard HJ, et al. Determinants of the elimination of methotrexate and 7-hydroxy-methotrexate following high-dose infusional therapy to cancer patients. Br J Clin Pharmacol. 2006;62:71-80.

16. Webb M. Inactivation of analogues of folic acid by certain non-exacting bacteria. Biochim Biophys Acta. 1955;17:212-225.

17. Levy CC, Goldman P. The enzymatic hydrolysis of methotrexate and folic acid. J Biol Chem. 1967;242:2933-2938. 
18. Goldman P, Levy CC. Carboxypeptidase G: purification and properties. Proc Natl Acad Sci U S A. 1967;58:1299-1306.

19. Pratt AG, Crawford EJ, Friedkin M. The hydrolysis of mono-, di-, and triglutamate derivatives of folic acid with bacterial enzymes. $J$ Biol Chem. 1968;243:6367-6372.

20. McCullough JL, Chabner BA, Bertino JR. Purification and properties of carboxypeptidase G1. J Biol Chem. 1971;246:7207-7213.

21. Albrecht AM, Boldizsar E, Hutchison DJ. Carboxypeptidase displaying differential velocity in hydrolysis of methotrexate, 5-methyltetrahydrofolic acid, and leucovorin. J Bacteriol. 1978;134:506-513.

22. Minton NP, Atkinson T, Sherwood RF. Molecular cloning of the Pseudomonas carboxypeptidase G2 gene and its expression in Escherichia coli and Pseudomonas putida. J Bacteriol. 1983;156: 1222-1227.

23. Minton NP, Atkinson T, Bruton CJ, Sherwood RF. The complete nucleotide sequence of the Pseudomonas gene coding for carboxypeptidase G2. Gene. 1984;31:31-38.

24. Sherwood RF, Melton RG, Alwan SM, Hughes P. Purification and properties of carboxypeptidase G2 from Pseudomonas sp. strain RS-16. Use of a novel triazine dye affinity method. Eur J Biochem. 1985;148:447-453.

25. Rowsell S, Pauptit RA, Tucker AD, Melton RG, Blow OM, Brick P. Crystal structure of carboxypeptidase G2, a bacterial enzyme with applications in cancer therapy. Structure. 1997;5:337-347.

26. Carter EL, Jager L, Gardner L, Hall CC, Willis S, Green JM. Escherichia coli abg genes enable uptake and cleavage of the folate catabolite p-aminobenzoyl-glutamate. J Bacteriol. 2007;189:3329-3334.

27. Green JM, Hollandsworth R, Pitstick L, Carter EL. Purification and characterization of the folate catabolic enzyme $p$-aminobenzoyl-glutamate hydrolase from Escherichia coli. J Bacteriol. 2010;192:2407-2413.

28. Hussein MJ, Green JM, Nichols BP. Characterization of mutations that allow $p$-aminobenzoyl-glutamate utilization by Escherichia coli. J Bacteriol. 1998;180:6260-6268.

29. Widemann BC, Sung E, Anderson L, et al. Pharmacokinetics and metabolism of the methotrexate metabolite 2, 4-diaminoN(10)-methylpteroic acid. J Pharmacol Exp Ther. 2000;294:894-901.

30. Monahan BP, Allegra CJ. Antifolates. In: Chabner BA, Longo DL, editors. Cancer Chemotherapy and Biotherapy: Principles and Practice. 4th ed. Philadelphia, PA: Lippincott, Williams \& Wilkins; 2006.

31. Adamson PC, Balis FM, McCully CL, et al. Rescue of experimental intrathecal methotrexate overdose with carboxypeptidase-G2. J Clin Oncol. 1991;9:670-674.

32. Adamson PC, Balis FM, McCully CL, Godwin KS, Poplack DG. Methotrexate pharmacokinetics following administration of recombinant carboxypeptidase-G2 in rhesus monkeys. J Clin Oncol. 1992;10:1359-1364.

33. Chabner BA, Johns DG, Bertino JR. Enzymatic cleavage of methotrexate provides a method for prevention of drug toxicity. Nature. 1972;239:395-397.

34. Stoller RG, Hande KR, Jacobs SA, Rosenberg SA, Chabner BA. Use of plasma pharmacokinetics to predict and prevent methotrexate toxicity. N Engl J Med. 1977;297:630-634.

35. Hansen HH, Selawry OS, Holland JF, McCall CB. The variability of individual tolerance to methotrexate in cancer patients. $\mathrm{Br} J$ Cancer. 1971;25:298-305.

36. Zoubek A, Zaunschirm HA, Lion T, et al. Successful carboxypeptidase $\mathrm{G}(2)$ rescue in delayed methotrexate elimination due to renal failure. Pediatr Hematol Oncol. 1995;12:471-477.

37. Widemann BC, Balis FM, Murphy RF, et al. Carboxypeptidase-G2, thymidine, and leucovorin rescue in cancer patients with methotrexateinduced renal dysfunction. J Clin Oncol. 1997;15:2125-2134.

38. DeAngelis LM, Tong WP, Lin S, Fleisher M, Bertino JR. Carboxypeptidase G2 rescue after high-dose methotrexate. $J$ Clin Oncol. 1996;14:2145-2149.

39. Krackhardt A, Schwartz S, Korfel A, Thiel E. Carboxypeptidase G2 rescue in a 79 year-old patient with cranial lymphoma after high-dose methotrexate induced acute renal failure. Leuk Lymphoma. 1999;35: 631-635.
40. Krause AS, Weihrauch MR, Bode U, et al. Carboxypeptidase-G2 rescue in cancer patients with delayed methotrexate elimination after high-dose methotrexate therapy. Leuk Lymphoma. 2002;43:2139-2143.

41. Widemann BC, Hetherington ML, Murphy RF, Balis FM, Adamson PC. Carboxypeptidase-G2 rescue in a patient with high dose methotrexateinduced nephrotoxicity. Cancer. 1995;76:521-526.

42. Park ES, Han KH, Choi HS, Shin HY, Ahn HS. Carboxypeptidase-G2 rescue in a patient with high dose methotrexate-induced nephrotoxicity. Cancer Res Treat. 2005;37:133-135.

43. Esteve MA, Devictor-Pierre B, Galy G, et al. Severe acute toxicity associated with high-dose methotrexate (MTX) therapy: use of therapeutic drug monitoring and test-dose to guide carboxypeptidase G2 rescue and MTX continuation. Eur J Clin Pharmacol. 2007;63:39-42.

44. Peyriere H, Cociglio M, Margueritte G, Vallat C, Blayac JP, Hillaire-Buys D. Optimal management of methotrexate intoxication in a child with osteosarcoma. Ann Pharmacother. 2004;38:422-427.

45. Qudsi R, Abdulhadi O, Sultan I. Low-dose carboxypeptidase-G2 for methotrexate toxicity in a child. Pediatr Blood Cancer. 2010;55: 1439-1440.

46. Vilay AM, Mueller BA, Haines H, Alten JA, Askenazi DJ. Treatment of methotrexate intoxication with various modalities of continuous extracorporeal therapy and glucarpidase. Pharmacotherapy. 2010; 30:111.

47. Buchen S, Ngampolo D, Melton RG, et al. Carboxypeptidase G2 rescue in patients with methotrexate intoxication and renal failure. Br J Cancer. 2005;92:480-487.

48. Schwartz S, Borner K, Muller K, et al. Glucarpidase (carboxypeptidase g2) intervention in adult and elderly cancer patients with renal dysfunction and delayed methotrexate elimination after high-dose methotrexate therapy. Oncologist. 2007;12:1299-1308.

49. Widemann BC, Balis FM, Kim A, et al. Glucarpidase, leucovorin, and thymidine for high-dose methotrexate-induced renal dysfunction: clinical and pharmacologic factors affecting outcome. J Clin Oncol. 2010;28:3979-3986.

50. Christensen AM, Pauley JL, Molinelli AR, et al. Resumption of high-dose methotrexate after acute kidney injury and glucarpidase use in pediatric oncology patients. Cancer. 2012;118:4321-4380.

51. Widemann BC, Jayaprakash N, Howard SC, Daugherty C, Chauhan RK, Rush J. Clinical trial and compassionate use experience with glucarpidase for methotrexate toxicity. J Clin Oncol. 2012;Suppl 30: 6530.

52. Phillips M, Smith W, Balan G, Ward S. Pharmacokinetics of glucarpidase in subjects with normal and impaired renal function. J Clin Pharmacol. 2008;48:279-284.

53. Hempel G, Lingg R, Boos J. Interactions of carboxypeptidase G(2) with 6S-leucovorin and 6R-leucovorin in vitro: implications for the application in case of methotrexate intoxications. Cancer Chemother Pharmacol. 2005;55:347-353.

54. Levitt M, Mosher MB, DeConti RC, et al. Improved therapeutic index of methotrexate with "leucovorin rescue". Cancer Res. 1973;33: 1729-1734.

55. Bernard S, Etienne MC, Fischel JL, Formento P, Milano G. Critical factors for the reversal of methotrexate cytotoxicity by folinic acid. $\mathrm{Br}$ J Cancer. 1991;63:303-307.

56. Capizzi RL, DeConti RC, Marsh JC, Bertino JR. Methotrexate therapy of head and neck cancer: improvement in therapeutic index by the use of leucovorin "rescue". Cancer Res. 1970;30:1782-1788.

57. Goldin A, Mantel N, Greenhouse SW, Venditti JM, Humphreys SR. Effect of delayed administration of citrovorum factor on the antileukemic effectiveness of aminopterin in mice. Cancer Res. 1954;14: $43-48$.

58. Bertino JR, Levitt M, McCullough JL, Chabner B. New approaches to chemotherapy with folate antagonists: use of leucovorin "rescue" and enzymic folate depletion. Ann N Y Acad Sci. 1971;186:486-495.

59. Binscheck T, Ambach L, Grobosch T, Schwartz S. Glucarpidase a fast and efficient antidote in methotrexate poisoning. Clin Toxicol. 2010;48:299. 
60. Voraxaze ${ }^{\circledR}$ (glucarpidase, full prescribing information). West Conshohocken, PA: BTG International Inc; 2012.

61. O'Marcaigh AS, Johnson CM, Smithson WA, et al. Successful treatment of intrathecal methotrexate overdose by using ventriculolumbar perfusion and intrathecal instillation of carboxypeptidase G2. Mayo Clin Proc. 1996;71:161-165.

62. Widemann BC, Balis FM, Shalabi A, et al. Treatment of accidental intrathecal methotrexate overdose with intrathecal carboxypeptidase G2. J Natl Cancer Inst. 2004;96:1557-1559.

63. Gervasini G. Polymorphisms in methotrexate pathways: what is clinically relevant, what is not, and what is promising. Curr Drug Metab. 2009;10:547-566.

64. Castaldo P, Magi S, Nasti AA, et al. Clinical pharmacogenetics of methotrexate. Curr Drug Metab. 2011;12:278-286.

65. Chabner BA, Chello PL, Bertino JR. Antitumor activity of a folatecleaving enzyme, carboxypeptidase G1. Cancer Res. 1972;32: 2114-2119.

66. Kalghatgi KK, Moroson BA, Horvath C, Bertino JR. Enhancement of antitumor activity of 2,4-diamino-5-( $3^{\prime}, 4^{\prime}$-dichlorophenyl)6-methylpyrimidine and Baker's antifol (triazinate) with carboxypeptidase G1. Cancer Res. 1979;39:3441-3445.

67. Romanini A, Sobrero AF, Chou TC, Sherwood RF, Bertino JR. Enhancement of trimetrexate cytotoxicity in vitro and in vivo by carboxypeptidase G2. Cancer Res. 1989;49:6019-6023.

68. Melton RG, Wiblin CN, Baskerville A, Foster RL, Sherwood RF. Covalent linkage of carboxypeptidase G2 to soluble dextrans-II. In vivo distribution and fate of conjugates. Biochem Pharmacol. 1987;36: $113-121$.
69. Bagshawe KD, Springer CJ, Searle F, et al. A cytotoxic agent can be generated selectively at cancer sites. Br J Cancer. 1988;58:700-703.

70. Searle F, Bier C, Buckley RG, et al. The potential of carboxypeptidase G2-antibody conjugates as anti-tumour agents. I. Preparation of antihuman chorionic gonadotrophin-carboxypeptidase G2 and cytotoxicity of the conjugate against JAR choriocarcinoma cells in vitro. Br J Cancer. 1986;53:377-384.

71. Melton RG, Searle F, Sherwood RF, Bagshawe KD, Boden JA. The potential of carboxypeptidase G2: antibody conjugates as anti-tumour agents. II. In vivo localising and clearance properties in a choriocarcinoma model. Br J Cancer. 1990;61:420-424.

72. Senter PD. Activation of prodrugs by antibody-enzyme conjugates: a new approach to cancer therapy. FASEB J. 1990;4:188-193.

73. Blakey DC, Davies DH, Dowell RI, et al. Anti-tumour effects of an antibody-carboxypeptidase G2 conjugate in combination with phenol mustard prodrugs. Br J Cancer. 1995;72:1083-1088.

74. Pedley RB, Sharma SK, Hawkins RE, Chester KA. Antibody-directed enzyme-prodrug therapy. Methods Mol Med. 2004;90:491-514.

75. Davies LC, Friedlos F, Hedley D, et al. Novel fluorinated prodrugs for activation by carboxypeptidase G2 showing good in vivo antitumor activity in gene-directed enzyme prodrug therapy. $J$ Med Chem. 2005; 48:5321-5388.

76. Hedley D, Ogilvie L, Springer C. Carboxypeptidase-G2-based gene-directed enzyme-prodrug therapy: a new weapon in the GDEPT armoury. Nat Rev Cancer. 2007;7:870-879.

77. Hunter P. The fourth front against cancer. The first clinical trials to test engineered viruses that attack tumour cells have yielded promising results for future cancer therapies. EMBO Rep. 2011;12:769-771.
Therapeutics and Clinical Risk Management

\section{Publish your work in this journal}

Therapeutics and Clinical Risk Management is an international, peerreviewed journal of clinical therapeutics and risk management, focusing on concise rapid reporting of clinical studies in all therapeutic areas, outcomes, safety, and programs for the effective, safe, and sustained use of medicines. This journal is indexed on PubMed Central, CAS,

\section{Dovepress}

EMBase, Scopus and the Elsevier Bibliographic databases. The manuscript management system is completely online and includes a very quick and fair peer-review system, which is all easy to use. Visit http://www.dovepress.com/testimonials.php to read real quotes from published authors. 